https://doi.org/10.15407/ujpe63.7.660

N.O. KORSUNSKA,${ }^{1}$ I.V. MARKEVICH,${ }^{1}$ T.R. STARA,${ }^{1}$ L.V. BORKOVSKA, ${ }^{1}$ S. LAVORYK,${ }^{1}$ L.YU. MELNICHUK, ${ }^{2}$ O.V. MELNICHUK ${ }^{2}$

${ }^{1}$ V.E. Lashkaryov Institute of Semiconductor Physics, Nat. Acad. of Sci. of Ukraine (41, Prosp. Nauky, Kyiv 03028, Ukraine)

2 Mykola Gogol State University of Nizhyn

(2, Hrafska Str., Nizhyn 16600, Ukraine; e-mail: mov310310@gmail.com)

\title{
CORRELATION BETWEEN PHOTOLUMINESCENT AND PHOTOELECTRICAL PROPERTIES OF Mn-DOPED ZnO
}

\begin{abstract}
$\mathrm{ZnO}$ ceramics undoped and doped with manganese are investigated. The Mn content $N_{\mathrm{Mn}}$ is varied from $10^{19}$ to $10^{21} \mathrm{~cm}^{-3}$. The photoluminescence (PL), diffuse reflection, and photoconductivity $(P C)$ spectra are measured. The quenching of the self-activated $\mathrm{ZnO}$ emission and the appearance of the light absorption and PC are observed in the same spectral region (400$600 \mathrm{~nm}$ ) under the doping. Simultaneously, a week PL band peaked at $645 \mathrm{~nm}$ arose and was assigned to intra-shell transitions in $\mathrm{Mn}_{\mathrm{Zn}}^{2+}$ centers. Based on the analysis of obtained results, the quenching effect is attributed to the re-absorption of the self-activated $\mathrm{ZnO}$ emission by Mn ions. A scheme of electron transitions that allows an explanation of the low intensity of the Mn-related emission is proposed.

Ke ywords: zinc oxide, $\mathrm{Mn}^{2+}$, photoluminescence, photoconductivity.
\end{abstract}

\section{Introduction}

Zinc oxide doped with manganese attracts now much attention due to its potential application in spintronic devices. A room-temperature ferromagnetic based on this material is expected to be prepared [1], and the influence of various defects on the magnetic interaction in $\mathrm{ZnO}: \mathrm{Mn}$ is discussed [2]. Meanwhile, the energetic positions of Mn-related levels, as well as the mechanisms of excitation-recombination processes in $\mathrm{ZnO}: \mathrm{Mn}$, were not ascertained definitively. For the elucidation of these themes, the investigations of the photoluminescence (PL) and photoconductivity (PC) are quite effective.

It was shown that the doping with Mn always results in a drastic quenching of the self-activated $\mathrm{ZnO}$

(C) N.O. KORSUNSKA, I.V. MARKEVICH, T.R. STARA, L.V. BORKOVSKA, S. LAVORYK, L.YU. MELNICHUK, O.V. MELNICHUK, 2018 emission, which is usually explained by a decrease of the native defect concentrations [3-6] or by the formation of non-radiative recombination centers $[6$, 7]. As for the Mn-related emission, its presence is thus far a subject of the discussion. Some authors affirmed that such emission is generally absent [3$6]$, whereas the appearance of weak PL bands at 636 and $650 \mathrm{~nm}$ was observed after the doping of $\mathrm{ZnO}$ with $\mathrm{Mn}$ [8], [9]. At the same time, in $\mathrm{ZnS}$, ZnSe, CdS, and CdSe doped with manganese, the intense emission in the 580-600-nm spectral interval related to intrashell ${ }^{4} \mathrm{~T}_{1}-{ }^{6} \mathrm{~A}_{1}$ transitions in $\mathrm{Mn}^{2+}$ ions takes place [10]. Since the electron paramagnetic resonance data testify that $\mathrm{Mn}_{\mathrm{Zn}}^{2+}$ centers with sufficient concentration are formed in $\mathrm{ZnO}$ under the doping [8], in order to explain the absence of a similar effect in $\mathrm{ZnO}: \mathrm{Mn}$, the domination of nonradiative electron transitions related to these centers was supposed $[3,5,10]$. To elucidate the ori-

ISSN 2071-0194. Ukr. J. Phys. 2018. Vol. 63, No. 7 
gin of this phenomenon, the further investigation is required.

In the present work, the combined measurements of $\mathrm{PL}$, diffuse reflectance, and $\mathrm{PC}$ in $\mathrm{ZnO}: \mathrm{Mn}$ ceramics were performed, and the scheme of electron transitions based on the analysis of obtained results was proposed.

\section{Experimental}

The samples were formed of the mixture of a $\mathrm{ZnO}$ powder (99.99\% purity) with distilled water or a $\mathrm{MnSO}_{4}$ aqueous solution, dried at room temperature, sintered in air for three hours at $1000{ }^{\circ} \mathrm{C}$, and cooled with a furnace. The concentration of $\mathrm{Mn}\left(N_{\mathrm{Mn}}\right)$ varied from $10^{19}$ to $10^{21} \mathrm{~cm}^{-3}$. The X-ray diffraction analysis did not reveal the presence of other Mn-related phases in the samples. Diffuse reflectance spectra were recorded with respect to the $\mathrm{BaSO}_{4}$ standard by a double-beam spectrometer UV-3600 UV-VIS NIR (Shimadzu Company) equipped with an integrated sphere ISP-3100. The obtained spectra were transformed in absorption ones, by using a standard program based on the Kubelka-Munk ratio. Photoconductivity (PC) and photoluminescence (PL) were measured, by using the Xe-lamp light passing through a grating monochromator as an exciting source. For the PC measurements, the ohmic indium electrodes were melted on the samples.

\section{Results and Discussion}

PL (a), diffuse reflectance $(b)$, and PC (c) spectra measured at room temperature in the samples with different Mn contents are shown in Fig. 1.

It is seen that the quenching of the self-activated $\mathrm{ZnO}$ emission [11] and its red shift occur due to the doping with Mn. Both effects enhance, and, so, the PL quenching spreads gradually from the blue to red spectral region with increasing $N_{\mathrm{Mn}}$. Simultaneously, an unstructured "tail" in the visible spectral region arises in diffusion reflectance spectra side-by-side with the exciton peak at $380 \mathrm{~nm}$. At first, this tail exhibits itself as a shoulder and then intensifies, spreads from 400 to $600 \mathrm{~nm}$, and transforms into a well-defined band. A similar effect was observed in $\mathrm{ZnO}$ : Mn by a number of investigators and was attributed to the absorption of incident photons by $\mathrm{Mn}_{\mathrm{Zn}}^{2+}$ ions due to intrashell transitions from the ground to excited states [12-14]. The absence of any structure in the absorption spectra, as well as high extinction coefficients,

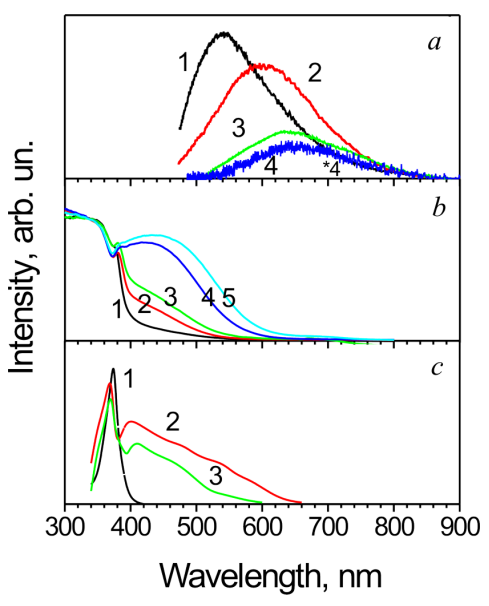

Fig. 1. RT PL $(a)$, diffuse reflectance, $(b)$ and PC $(c)$ spectra of $\mathrm{ZnO}: \mathrm{Mn}$ ceramics with different $\mathrm{Mn}$ contents. PL was excited at $\lambda=365 \mathrm{~nm}$. $a$-pure $\mathrm{ZnO}(1) ; 10^{19}$ (2); $10^{20}$ (3); $10^{21} \mathrm{~cm}^{-3}$ (4). $b-10^{19}$ (1); $5 \times 10^{19}$ (2); $10^{20}$ (3); $5 \times 10^{20}(4) ; 10^{21} \mathrm{~cm}^{-3}(5) . c$ - pure $\mathrm{ZnO}(1) ; 5 \times 10^{20}$ (2); $1 \times 10^{20} \mathrm{~cm}^{-3}(3)$

led to the supposition that this effect is caused by the transitions of electrons from Mn-related energy levels to the band continuum [10]. This supposition is confirmed by PC measurements. In fact, the PC spectrum of undoped $\mathrm{ZnO}$ exhibits the only narrow peak, whose position coincides with that of free excitons, whereas, under doping with $\mathrm{Mn}$, an additional $\mathrm{PC}$ appeared in the same spectral interval, where the Mn-related absorption takes place. Such effect was observed also in [14]. Thus, free electrons appear as a result of the light absorption by Mn-related centers.

Since the spectral region of the Mn-related reflectance coincides with that of the PL quenching, and both change similarly with increasing $N_{\mathrm{Mn}}$, one can conclude that a decrease of the PL intensity under the doping is due to the re-absorption of a selfactivated $\mathrm{ZnO}$ emission by Mn-related centers. The analysis of the emission spectra of the same $\mathrm{ZnO}: \mathrm{Mn}$ ceramics by means of the Gaussian deconvolution showed [15] that, side-by-side with the quenching of the self-activated emission, a new PL band peaked at $645 \mathrm{~nm}$ appeared. This band enhanced gradually with respect to other ones with increasing the $\mathrm{Mn}$ content and became dominant in the PL spectrum at $N_{\mathrm{Mn}}=10^{20} \mathrm{~cm}^{-3}$ [15]. An enhancement of the 645$\mathrm{nm}$ emission accompanied by the suppression of other PL bands gives possibility to attribute this emission to radiative electron transitions in Mn-related centers 

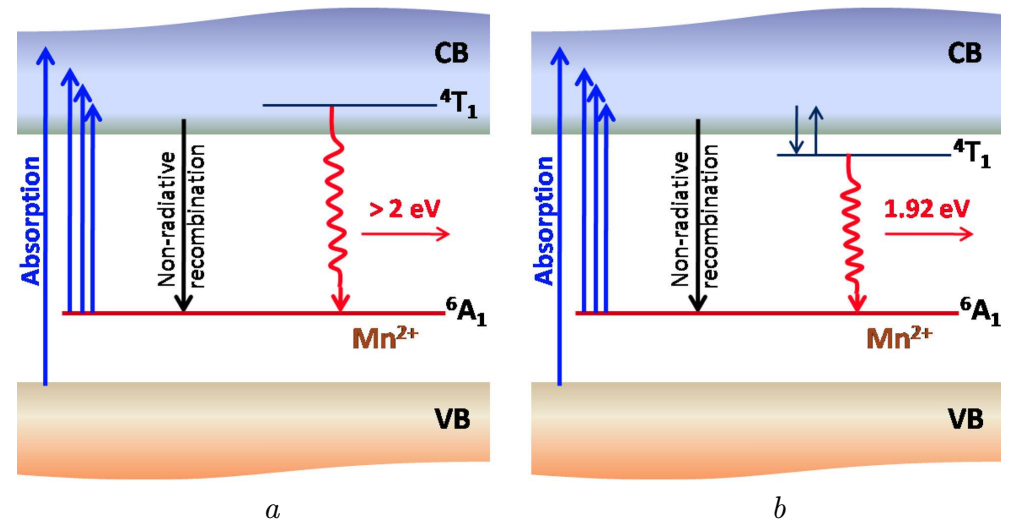

Fig. 2. Schemes of electron transitions related to the $\mathrm{MnZn}^{2+}$ center: ${ }_{4} \mathrm{~T}^{1}$ level is in the conduction band $(a)$ and below it $(b)$



Fig. 3. $\mathrm{PL}$ spectra of a $\mathrm{ZnO}: \mathrm{Mn}$ sample with $N_{\mathrm{Mn}}=1 \times$ $\times 10^{20} \mathrm{~cm}^{-3}$ at RT (1) and $77 \mathrm{~K}(2)$

[15]. The absolute intensity of this band, however, is rather week.

The weakness of the 645 -nm PL band testifies that the intensity of the radiative recombination of free electrons excited from $\mathrm{Mn}$ ions is rather low. So, the presence of some processes that hamper the radiative capture of free electrons onto the ground state of $\mathrm{Mn}_{\mathrm{Zn}}^{2+}$ centers should be supposed. One of such processes is based on the assumption that the optical absorption is caused by the electron transition from ${ }^{6} \mathrm{~A}_{1}$ level to the conduction band (c-band) [14]. In this case, the subsequent capture of an excited electron by a $\mathrm{Mn}_{\mathrm{Zn}}$ ion occurs in the attractive field of the positive charge and is assumed to be fast and non-radiative [14]. On the other hand, the PL band at about $650 \mathrm{~nm}$ observed in $[8,9,15]$ and the present work can be attributed to radiative electron transitions in Mn-related centers. Thus, the existence of two ways of the photoelectron capture by $\mathrm{Mn}_{\mathrm{Zn}}^{2+}$ centers should be thought, one of which is the direct recombination of a free electron to the ${ }^{6} \mathrm{~A}_{1}$ level, and another one is the electron capture through the ${ }^{4} \mathrm{~T}_{1}$ level. Therefore, the Mn-related emission intensity should be determined by the competition of these recombination ways. It is supposed usually that the ${ }^{4} \mathrm{~T}_{1}$ level is located in the $c$-band $[10,14]$ (Fig. 2, a). In this case, the radiative intrashell transition in $\mathrm{Mn}_{\mathrm{Zn}}$ center can take place due to the thermal excitation of a free electron to the ${ }^{4} \mathrm{~T}_{1}$ level. So, the Mn-related emission intensity has to drop, as the temperature decreases. However, the position of the ${ }^{4} \mathrm{~T}_{1}$ level below the $c$-band edge, when this level acts as a shallow trap, can be also considered (Fig. 2, b). In this case, the intensity of Mn-related band will increase with decreasing the temperature due to a slowdown of the thermal escape of the electron captured by the ${ }^{4} \mathrm{~T}_{1}$ level.

To verify which of two schemes shown in Fig. 2 is realized, the $\mathrm{PL}$ spectra of a $\mathrm{ZnO}: \mathrm{Mn}$ sample with $N_{\mathrm{Mn}}=1 \times 10^{20} \mathrm{~cm}^{-3}$ measured both at RT and 77 $\mathrm{K}$ were compared. It was found that a considerable enhancement of the $645-\mathrm{nm}$ PL band intensity takes place under the cooling of the sample (Fig. 3).

It should be noted that, when the ${ }^{4} \mathrm{~T}_{1}$ level is located in the $c$-band, the probability of an intrashell transition should be very low, because the recombination time due to the direct capture of a free electron has to be much shorter than that due to the intrashell transition. In addition, the emission quantum will exceed, in this case, the energy distance between the $c$-band edge and the ${ }^{6} \mathrm{~A}_{1}$ level which is considered 
to be somewhat higher than $2 \mathrm{eV}[14]$. At the same time, the experimentally measured energy of the Mnrelated emission is lower than $2 \mathrm{eV}$, which corresponds to scheme $(b)$ in Fig. 2. So, the location of the ${ }^{4} \mathrm{~T}_{1}$ level under the $c$-band edge can be thought to realize.

\section{Conclusion}

In $\mathrm{ZnO}$ : Mn ceramics, we have measured the photoluminescence, diffuse reflectance, and photoconductivity spectra. The Mn content was varied from $10^{19}$ to $10^{21} \mathrm{~cm}^{-3}$. As a result of the Mn doping, the quenching of the self-activated $\mathrm{ZnO}$ emission and the appearance of light absorption and photoconductivity in the 400-600-nm spectral interval were observed, which was accounted for by the electron transitions from $\mathrm{Mn}_{Z n}$ centers to the $c$-band. Simultaneously, a new emission band with a rather week intensity peaked at $645 \mathrm{~nm}$ arose. This band, however, is intensified with respect to other ones with increasing the $\mathrm{Mn}$ content and becomes dominant at $N_{\mathrm{Mn}}=10^{20} \mathrm{~cm}^{-3}$, which allowed its attribution to the intrashell ${ }^{4} \mathrm{~T}_{1}-$ ${ }^{6} \mathrm{~A}_{1}$ transitions in $\mathrm{Mn}_{\mathrm{Zn}}^{2+}$ centers. To explain the weak intensity of the Mn-related emission, the photoelectron recombination on Mn-related centers was supposed to occur in two ways. The first one implies the nonradiative capture of a free electron to the ${ }^{6} \mathrm{~A}_{1}$ level directly. The second one consists in the capture of an electron on the excited ${ }^{4} \mathrm{~T}_{1}$ level and the further radiative recombination on the ${ }^{6} \mathrm{~A}_{1}$ level. The last transition results in the $645-\mathrm{nm}$ emission. Since the $645-$ $\mathrm{nm}$ band intensity was found to increase essentially under the cooling of a sample from RT to $77 \mathrm{~K}$, it should be concluded that the ${ }^{4} \mathrm{~T}_{1}$ level is located below the $c$-band edge and act as a shallow trap. Since the quenching of the self-activated $\mathrm{ZnO}$ emission due to the Mn doping occurred in the same spectral region as the Mn-related absorption, this effect is supposed to be due to the reabsorption of the emitted light by Mn-related centers.

This work was partially supported by the National Academy of Sciences of Ukraine through the project "Physics and technology of multifunctional materials and structures based on oxides of metals, silicon, III-V and II-VI compounds for applications in the novel devices of optoelectronics, microelectronics and UHF technology" (Grant No. III-4-16) and by the Ministry of Education and Science of Ukraine via the project "Effect of the doping on structural, optical and electron-phonon properties and stability of anisotropic crystals (Grant No. 89452)".

1. T. Dietl, H. Ohno, F. Matsukura, J. Cibert, D. Ferrand. Zener model description of ferromagnetism in zinc-blende magnetic semiconductors. Science 287, 1019 (2000).

2. D. Iuean, B. Sanyal, O. Eriksson. Influence of defects on the magnetism of Mn-doped ZnO. J. Appl. Phys. 101 09H101 (1) (2007).

3. M. Liu, A.h. Kitai, P. Mascher. Point defects and luminescence centers in zinc oxide and zinc oxide doped with manganese. J. Lumin. 54, 35 (1992).

4. X.T. Zhang, Y.C. Liu, J.Y. Zhang, Y.M. Lu, D.Z. Shen, X.W. Fan, X.G. Kong. Structure and photoluminescence of Mn-passivated nanocrystalline $\mathrm{ZnO}$ thin films. J. Crystal Growth 254, 80 (2003).

5. U. Llyas, R.S. Rawat, Y. Wang, T.L. Tan, P. Lee, R. Chen, H.D. Sun, F. Li, S. Zhang. Alteration of Mn exchange coupling by oxygen interstitials in $\mathrm{ZnO}: \mathrm{Mn}$ thin films. Appl. Surf. Sci. 258, 6373 (2012).

6. M. Sima, L. Mihut, E. Vasile, Ma. Sima, C. Logofatu. Optical properties of $\mathrm{Mn}$-doped $\mathrm{ZnO}$ films and wires synthesized by thermal oxidation of ZnMn alloy. Thin Solid Films 590, 141 (2015).

7. M. Godlewski, A. Wojcik-Glodowska, E. Guziewicz, S. Yatsunenko, A. Zakrzewski, Y. Dumont, E. Chikoidze, M.R. Phillips. Optical properties of manganese doped wide band gap ZnS and ZnO. Optical Materials 31, 1751 (2009).

8. A.J. Reddy, M.K. Kokila, H. Nagabhushana, J.L. Rao, B.M. Nagabhushana, C. Shivakumara, R.P.S. Chacradhar. EPR and photoluminescence studies oh $\mathrm{ZnO}: \mathrm{Mn}$ nanophosphors prepared by solution combustion route. Spectrochimica Acta (A) 79, 476 (2011).

9. Th.L. Plan. Structural, optical and magnetic properties of polycrystalline $\mathrm{Zn}_{1-x} \mathrm{Mn}_{x} \mathrm{O}$ ceramics. Sol. St. Commun. 151, 24 (2011).

10. R. Beaulac, P.I. Archer, D.R. Gamelin. Luminescence in colloidal $\mathrm{Mn}^{2+}$-doped semiconductor nanocrystals. J. Sol. St. Chemistry 181, 1582 (2008).

11. I. Markevich, T. Stara, L. Khomenkova, V. Kushnirenko, L. Borkovska. Photoluminescence engineering in polycrystalline $\mathrm{ZnO}$ and $\mathrm{ZnO}$-based compounds. AIMS Materials Science 3, 486 (2016).

12. E. Chikoidze, Y. Dumont, F. Jomard, O. Gorochov. Electrical and optical properties of $\mathrm{ZnO}: \mathrm{Mn}$ thin films grown by MOCVD. Thin Solid Films 515, 8519 (2007).

13. Q. Ma, X. Lv, Y. Wang, J. Chen. Optical and photocatalytic properties of $\mathrm{Mn}$ doped flower-like $\mathrm{ZnO}$ hierarchical structures. Opt. Mater. 6086 (2016).

14. C.A. Johnson, K.R. Kittilstved, T.C. Kaspar, T.C. Droubay, S.A. Chambers, G.M. Salley, D.R. Gamelin. Mid-gap electronic states in $\mathrm{Zn}_{1-x} \mathrm{Mn}_{x}$ O. Phys. Rev. B 82, 115202 1 (2010).

15. T.R. Stara, I.V. Markevich. Influence of Mn doping on $\mathrm{ZnO}$ defect-related emission. Semiconductor physics, quantum electronics and optoelectronics 20, 137 (2017).

Received 18.02.18 
Н.О. Корсунсъка, I.В. Маркевич,

Т.Р. Стара, Л.В. Борковсъка, С. Лаворик,

Л.Ю. Мельничук, О.В. Мельничук

КОРЕЛЯЦІЯ МІЖ ФОТОЛЮМІНЕСЦЕНТНИМИ

ТА ФОТОЕЛЕКТРИЧНИМИ ВЛАСТИВОСТЯМИ ZnО, ЛЕГОВАНОГО Мn

Р е $з$ ю м е

Досліджено кераміку $\mathrm{ZnO}$, нелеговану та леговану марганцем. Концентрація марганцю змінювалась від $10^{19}$ до $10^{21} \mathrm{~cm}^{-3}$. Вимірювались спектри фотолюмінесценції (ФЛ), дифузного відбивання та фотопровідності (ФП). У легованих зразках спостерігалось гасіння самоактивованого випромінювання, а також поява поглинання світла та ФП у спектральній області 400-600 нм. Одночасно спостерігалась поява смуги слабкої ФЛ з положенням 645 нм, пов'язаної 3 внутрішньоцентровими переходами в центрах $\mathrm{Mn}_{\mathrm{Zn}}^{2+}$. На підставі аналізу одержаних результатів ефект гасіння було приписано перепоглинанню самоактивованого випромінювання $\mathrm{ZnO}$ йонами $\mathrm{Mn}$. Запропоновано схему електронних переходів, що дозволяє пояснити низьку інтенсивність випромінювання, пов'язаного з $\mathrm{Mn}$. 